\title{
DOCTORAL DISSERTATIONS
}

"Church and State in Republican China. A Survey History of the Relations between the Christian Church and the Chinese Government, 1911-1945." By Arne B. Sovik (17 Rte. de Malagnou, Geneva, Switzerland). Yale University, 1952.

Director : K. S. Latourette.

The Ming Empire had admitted Roman Catholic Christianity into China with some hesitation. After a period of tentative tolerance the Manchus forbade the propagation of the faith for two reasons: first, it feared the Church as the vanguard of Western aggression; second, the alien ideology of the Church was a threat to the Confucian pattern of society and government. In the nineteeneth century Christian missions countered the attack of the Empire by entering under the protection of a system of treaty rights forced upon China by the Western powers. The churches were therefore in a state of irreconcilable conflict, sometimes overt, sometimes latent, with the Empire.

This is the background for the period discussed in this dissertation. The Republican period saw the gradual elimination of the major causes of tension between church and government and the growth of friendly relations.

When the Empire crumbled and the Confucian pattern was disregarded, one of the nascent Republic's first acts was to declare full religious freedom. This was the first step in effecting a reconciliation. Through the years the concept of religious liberty gained strength. But at the same time the growth of popular secularism and nationalism led to the establishment of a government which, while insisting that it was not religious, assumed some of the prerogatives of religion and threatened the freedom of action of the church (in education, for example). Meanwhile the way was opened for the church to sever its relations with foreign powers, whose protection was theoretically unnecessary and was practically an increasing embarrassment. This severance of relations was finally accomplished in 1943, with the abrogation of the "unequal treaties." It came about not so much through the efforts of the church as through changes in international politics and through the pressure of China's new nationalism.

The process of reconciliation between church and state was complicated by many factors, among them the ancient resentments, foreign missionary dominance in the churchwhich linked it with foreign imperialism, the tumultuous times, and the tendency toward secular totalitarianism in the Kuomintang. Reconciliation was fostered by such factors as the presence in government of many men of Christian faith or ideals, the evident concern of the Christians for China's welfare, the growing strength of Chinese leadership in the church, common concern over the problem of Communism, and the weakness of the totalitarian factor in the Kuomintang Government.

In 1945, when this study ends, the churches and the Government were in friendly if somewhat ambiguous relations. Two dangers threatened: the discrimination of the Kuomintang Government and the rise of Communist power.

"Methodist Theology in Great Britain in the Nineteenth Century, with Special Reference to the Theology of Adam Clarke, Richard Watson, and William Burt Pope." By Elden Dale Dunlap (Southwestern College, Winfield, Kan.). Yale University, 1956. Directors: Raymond P. Morris, Albert C. Outler.

Problem: An analysis and interpretation of the main strands and deter- 